\title{
Human dimensions of gain and loss of plant species diversity surrounding oil palm plantations
}

\author{
Farras Imantoko $^{1 *}$, Arzyana Sunkar ${ }^{2}$, and Yanto Santosa ${ }^{3}$ \\ ${ }^{1}$ Department of Forest Resources Conservation and Ecotourism, Faculty of Forestry, Bogor \\ Agricultural University P.O Box 168 Bogor, Indonesia \\ ${ }^{2}$ Protected Area Management Division, Department of Forest Resources Conservation and \\ Ecotourism, Faculty of Forestry, Bogor Agricultural University P.O Box 168 Bogor, \\ Indonesia \\ ${ }^{3}$ Ecology and Wildlife Management Division, Department of Forest Resources Conservation \\ and Ecotourism, Faculty of Forestry, Bogor Agricultural University P.O Box 168 Bogor, \\ Indonesia
}

\begin{abstract}
Changes in plants diversity occurring the establishment of oil palm plantations, have been considered as the reasons for the changing pattern in community livelihoods. Hence, the values of plants diversity to the local community worth considering. This research was conducted to identify the local communities' perceptions related to gain and loss of plant species diversity due to the establishment of oil palm plantation. The study was carried out in the indigenous Dayak Villages of Tajok Kayong and Nanga Tayap, West Kalimantan Province of Indonesia in March 2018. Data were collected using field observation and interviews. Our results indicate that the establishment of oil palm plantation have resulted in the gain of 3 plant species and the loss of 8 plant species functional values (medicine and food). Nevertheless, as many as $75.68 \%$ of interviewed person stated that the presence of oil palm plantations increased plant diversity, in terms of flowering plants and other non-functional plants. These findings reveals that local community were not affected by the species loss since prior to the plantation's establishment, their living patterns were already transformed into semi modern and modern living styles in which the people have lower dependence on their surrounding plants.
\end{abstract}

\section{Background}

\footnotetext{
* Corresponding author: farrasimntk@gmail.com
} 
The existence of biodiversity has a very important value for communities just like the Dayak people who rely on life pattern and life fulfilment system to the environment. Soni [1] asserts that the Dayak people consider their land or territory as a means for their survival and culture thus showing that lands and territories containing natural resources are very important. Rifai \& Walujo [2], stated that ethnobotanical studies should be able to describe the cultural relations of the community, especially the perception and conception of the community in understanding natural plant resources in the environment in which they live. So this makes the presence of oil palm plantations necessary to be seen through community perspectives because this phenomenon often gets accusations that lead to the loss of biodiversity, especially in plants species.

The expansion of oil palm plantations in Indonesia is very significant indeed, according to Ditjenbun [3] the estimated area of oil palm plantations in Indonesia reached 12.3 million hectares in 2017. This area supports the status of Indonesia as the largest palm oil exporting country in the world (Budidarsono et al) [4]. West Kalimantan is one of the tropical rain forest area in Indonesia which harbours a high diversity of plants and it is estimated to contain various types of plants that have potential as medicine (Budiasih) [5].

The rapid development of oil palm has led to several allegations [6]. Various research results suggest that oil palm expansion is thought to be the main cause of deforestation and biodiversity decline in Indonesia [7, 8, 9, 10]. Koh and Wilcove [11] assert that the conversion of primary forests or secondary forests to oil palm plantations has the effect of reducing species diversity. However, on the other hand the results of research from Santosa et al. [12] stated that there is an increase in the diversity of bird species, butterflies, herpetofauna and the density of earthworms on oil palm plantations based on the history of land cover. Such contradictory findings are interesting because they show that the impact of the oil palm plantations need to be investigated more deeply.

So the phenomenon of acquisition and loss of species of plants diversity after the establishment of oil palm plantations needs to be investigated while studying the of social, economic and cultural aspects point of views based on community perception in the field.

\section{Research Methodology}

\subsection{Time and Study sites}

The research was conducted around NTYE Palm Oil Plantation, Tajok Kayong Village and Nanga Tayap Village, Nanga Tayap Sub-District, West Kalimantan Province. The duration of our research was 1 month, starting from March 12, 2018.

\subsection{Instruments}

The instruments used in this research consists of audio recorder, Microsoft Excel, Microsoft Word, and camera. We used an interview guide that contains a list of structured questions and five-scale Likerts statements. 


\subsection{Data Collection}

Methods of data collection used to identify species diversity based on community perception were based on the interview. Interviews were conducted through openended interviews. Data were recorded under the the form of species composition from the knowledge of the community about the types of plants, both gain and lost or the type of increase and decrease species since the palm plantation was established and also the public perception related to it. The price data of the types of plants were obtained by economic valuation method by doing 3 types of approaches which are market value approach, replacement value approach and regulatory value approach.

In this study, respondents were indigenous Dayak people who were either related to oil palm cultivation or not with a total of people with a sampling unit of 1 person per family. This is because indigenous Dayak people are long-lived and settled in their residential areas around the oil palm plantations, so that whatever the type of work they do, they can still feel directly the impacts that result from the phenomenon of gain and loss of plant species.

The people in the village of Tajok Kayong and Nanga Tayap who are the respondents that entirely from the Dayak tribe and they accounted for 74 respondents. The Tajok Kayong Village has an area of $6.26 \%$ of the area of Nanga Tayap Subdistrict, while Nanga Tayap Village has an area of $4.98 \%$ of Nanga Tayap Sub-district (BPS Ketapang [13]). The types of jobs do vary, with quite high amounts of income as it could be seen from the status of children.There are some who continue studying up to University level, so this proves that the economic prosperity of the people is quite high. Given that one of the most common tribe on the island of Kalimantan is the Dayak community, it is in accordance with the statement [14] that the Dayak people are Kalimantan island residents who occupy a region permanently for a long time This supports the idea that West Kalimantan Province has its own uniqueness towards the process of acculturation, because of the Dayak people could face some modern way of living syle in several aspects.

\subsection{Data Analysis}

The analysis method used to measure the interaction of the community with the diversity of plant species and the perception of the local community was conducted using Quantitatively Descriptive method through Likert Scale that were coded $0=$ do not know, $1=$ strongly disagree, $2=$ disagree, $3=$ neutral, $4=$ agree, $5=$ strongly agree. It shows positive statements which become positive indication and negative form of negative statement becomes negative indication [15]. The distribution of responses from respondent each statement and each plants species that gain and loss/increased and decreased individually were diplayed in Tables.

\section{Results and Discussion}

\subsection{List of gain and loss plant species based on community perceptions.}

The existence of oil palm plantations around the village of Tajok Kayong and Nanga Tayap Village induce some changes in plant species diversity (either gain or loss). This phenomenon is felt by the community directly because they themselves feel that 
there are some types of plants that can never been found again, and also some types of plants that have only been discovered since the oil palm plantation was established. The types of plants listed in Table 1 below are the species identified by the community because they can well remember the species and its function at the time.

Table 1. List of types of loss and gain of plant species along with the average price based on the community.

\begin{tabular}{|c|c|c|c|c|}
\hline No. & Loss Species & Average Price & Gain Species & $\begin{array}{l}\text { Average } \\
\text { Price }\end{array}$ \\
\hline 1. & Shorea sp. & $\begin{array}{l}2.400 .000 \\
\mathrm{IDR} / \mathrm{m}^{3}\end{array}$ & $\begin{array}{l}\text { Diplazium } \\
\text { esculentum }\end{array}$ & $\begin{array}{l}2.000 \\
\text { IDR/bundle }\end{array}$ \\
\hline 2. & $\begin{array}{l}\text { Neolamarckia } \\
\text { cadamba }\end{array}$ & $950.000 \mathrm{IDR} / \mathrm{m}^{3}$ & Limnocharis flava & $\begin{array}{l}1.500 \\
\text { IDR/bundle }\end{array}$ \\
\hline 3. & Shorea sp. (wood) & $450.000 \mathrm{IDR} / \mathrm{m}^{3}$ & Ipomea aquatica & $\begin{array}{l}2.000 \\
\text { IDR/bundle }\end{array}$ \\
\hline 4. & $\begin{array}{l}\text { Shorea } \\
\text { sp./Tengkawang } \\
\text { (fruit) }\end{array}$ & $3.000 \mathrm{IDR} / \mathrm{Kg}$ & & \\
\hline 5. & $\begin{array}{lr}\text { Durian } & \text { hutan } \\
\text { "Pekawai" } & \text { (Durio } \\
\text { kutejensis) } & \\
\end{array}$ & $55.000 \mathrm{IDR} / \mathrm{Kg}$ & & \\
\hline 6. & Kusik (Red Durian) & $100.000 \mathrm{IDR} / \mathrm{Kg}$ & & \\
\hline 7. & Momordica sp. & $3.000 \mathrm{IDR} / \mathrm{Kg}$ & & \\
\hline 8. & $\begin{array}{l}\text { Artocarpus } \\
\text { anisophyllus }\end{array}$ & $5.000 \mathrm{IDR} / \mathrm{Kg}$ & & \\
\hline & TOTAL & $3.966 .000 \mathrm{IDR}$ & & $5.500 \mathrm{IDR}$ \\
\hline
\end{tabular}

Price-related data is also obtained from the knowledge of the community who had used the types of plants, so that in the end the economic valuation can be done based on the price gained from the knowledge of the community. The purpose of the valuation is to know how big the existing value of biodiversity is, because the existence of natural resources itself is the initial factor in the future process of economic activity involving natural resources [16].

The species of plants which can not be found again by the community include Shorea sp., Neolamarckia cadamba, Shorea sp/Tengkawang (wood and fruit), Durio kutejensis (pekawai), Momordica sp (Kusik), and Artocarpus anisophyllus. In the species of Meranti (Shorea sp.), people use these woody plants for building and other needs. The selling price of this meranti reaches $2.400,000 \mathrm{IDR} / \mathrm{m} 3$. Such type of meranti cannot be be found any more by the community, but the community does not suffer significant losses because they feel the need for more energy and a much time to enter the area and harvest this timber. This is in accordance with the results of the study from Sunkar et al. [17] which showed that distance is a factor affecting the rate of encroachment and positive interaction. Thus, this is in harmony with the people who feel heavy to travel to the location of woody plants due to needed amount of time and energy. Then, people who have experienced more advanced life changes also make their habits to buy more building materials, so they prefer to spend money to build their own homes and other buildings such as public facilities nearby.

There is also a type of forest durian called "pekawai" by local people which can not be found anymore. This type of plant has an economic value with a selling price of $55.000 \mathrm{IDR} / \mathrm{Kg}$. On the cultural side, there is a custom of the community that 
makes this type of pekawai a symbol of family heritage. Indeed, planting and caring for the tree for several generations train the young ones about the existence of pekawai so that the land has a marker linked with ancestors who planted the durian. This value is built by people who do have a high involvement in agricultural activities, so that the object used as a symbol will not be far from the crop itself. The system of knowledge possessed by society is traditionally a part of indigenous peoples culture and rural farmers [18]. So, even if the tradition of maintaining the pekawai has already faded away, it is important to know that it must be remembered for the future generation to grow, the culture can remain alive in the survival story in society.

In addition to the species that can not be found again, there are also new types of plants that can be found by the community with prices and benefits that can be taken from these types. The price and benefits of each species that emerged since the palm oil plantations become interesting, because it shows that the existence of oil palm plantations resulted in the gained of species biodiversity which also from the community has an economic value that can be utilized either directly or for sold to the market.

The types emerging from these plants include the Pakis (Diplazium esculentum) plant, with a selling price of $2.000 \mathrm{IDR} /$ bundle, Genjer (Limnocharis flava) with $1.500 \mathrm{IDR} /$ bundle, and Kangkung (Ipomea aquatica) with $2.000 \mathrm{IDR} / \mathrm{bundle}$. These plants are used by the community because they are increasingly encountered since the existence of oil palm plantations, where previously the community had never found this type of fern. Kaplan et.al [19] explain that within the ethnobotany discipline there is a set of assumptions about the relationship between behavioral patterns with integrated socio-cultural arrangements in the language, cognitive system, rules and codes of local cultural ethics. This shows that the pattern of human behavior in the utilization of several types of plants into something that will affect the incidence of value to the type. Given the new plant species or new natural resources, humans will naturally find a way to make use of them. This happens because humans seek to utilize natural resources and the environment based on their experience and knowledge [20].

The existence of some of these new species have an effect on the existing biodiversity. The higher value of species diversity in a habitat, the equilibrium of the community will be higher [21]. The economic value derived from this newly discovered plant species is important because it indicates the presence of palm oil can provide the positive impact is also to be felt directly by the people who live nearby because those plants were naturally gained.

\subsection{List of plant species that are decreased and increased individually based on community perceptions.}

In addition to the phenomenon of the gain and loss of biodiversity, there are also some types of plants that have increased and also decreased individually (Table 2). This is seen from the knowledge of the local community that Dayak people who feel to find more of some certain species which were less and more encountered by the community, so that types of species can be identified along with the price and its usefulness. 
Table 2. List of decreased and increased of plants individu along with the average price of the community.

\begin{tabular}{|l|l|l|l|l|}
\hline No. & $\begin{array}{l}\text { Decreased } \\
\text { Species }\end{array}$ & Average Price & Increased Species & Average Price \\
\hline 1. & $\begin{array}{l}\text { Korthalsia } \\
\text { flagellaris }\end{array}$ & $1.500 \mathrm{IDR} / \mathrm{Kg}$ & Imperata cylindrica & 0 \\
\hline 2. & Cucurbita sp & $8.000 \mathrm{IDR} / \mathrm{Kg}$ & $\begin{array}{l}\text { Volvarariella } \\
\text { volvacea }\end{array}$ & $\begin{array}{l}12.500 \\
\mathrm{IDR} / \mathrm{Kg}\end{array}$ \\
\hline 3. & $\begin{array}{l}\text { Curcuma } \\
\text { zanthorrhiza }\end{array}$ & $8.000 \mathrm{IDR} / \mathrm{Kg}$ & Turnera ulmifolia & 0 \\
\hline 4. & $\begin{array}{l}\text { Eurycoma } \\
\text { longifolia }\end{array}$ & $40.000 \mathrm{IDR} / \mathrm{Kg}$ & & \\
\hline 5. & $\begin{array}{l}\text { Tinospora } \\
\text { cordifolia }\end{array}$ & $35.000 \mathrm{IDR} / \mathrm{Kg}$ & & $12.500 \mathrm{IDR}$ \\
\hline 6. & $\begin{array}{l}\text { Eusideroxylon } \\
\text { zwageri }\end{array}$ & $16.500 .000 \mathrm{IDR} / \mathrm{m}^{3}$ & & \\
\hline 7. & $\begin{array}{l}\text { Shorea leavis } \\
\mathrm{Rp} 9.750 .000\end{array}$ & & \\
\hline & TOTAL & $26.342 .500 \mathrm{IDR}$ & & \\
\hline
\end{tabular}

There are several types of medicinal plants that have decreased the number of individuals based on the perception of the community, including species of Curcuma zanthorrhiza, Eurycoma longifolia and also Tinospora cordifolia, with total selling price of the three types include $83.000 \mathrm{IDR} / \mathrm{kg}$. Although they are perceived to be less in number by the community, they do not have a perceived influence because the level of dependence on the use of medicinal plants is very low, and also people realize that the use of generic medicine is clearly more efficient and it enables to save energy and time. In addition, the presence of general hospitals around their place make people change their habits and they now to prefer to come directly to seek doctors rather than plants in the forest that requires a lot of energy. This is in accordance with the results of Lovadi et al [22] who showed that harvesting plants in the forest is less effective to make people start thinking to plant or cultivate medicinal plants around the settlement or yard. So that changes in the pattern of community life was realized first before the Nanga Tayap oil palm plantation was built.

Furthermore, there are types of woody plants such as ulin (Eusideroxylon zwageri) and bengkirai (Shorea leavis) with selling price of $16.500 .000 \mathrm{IDR} / \mathrm{m} 3$ and $9.750 .000 \mathrm{IDR} / \mathrm{m} 3$ respectively. The perception of this species is not much different from the kind of woody plants that loss in the previous discussion, that the community feels no big influence on their lifestyle because of the existence of their habits that tend to buy directly the building materials rather than take and cut down trees from the forest which is considered as ineffective and a waste of time and energy.

Public perception about the use of medicinal plants is influenced by their style of life which is becoming more modern day by day, so this is in accordance with the statement by Waluyo [23] that the existence of modern life will change the original knowledge of ethnic Indonesians outside Java. Then, there are several types of plants such as tankos mushrooms (Volvarariella volvacea), reeds (Imperata cylindrica), and bunga pukul delapan (Turnera ulmifolia) to be often found by the community. This suggests that the phenomenon of biodiversity gain is ecologically felt by society as well. The type of plants with selling value is tankos mushroom which reach 12.500 
IDR/ Kg. This is interesting because in addition to the decreased or loss plant species, there are also increased plant individually such as the three species that are most remembered by the community.

\subsection{Perceptions of Dayak People on plants}

The presence of NTYE oil palm plantations surrounding the community caused some kind of changes in certain species of plants. It is important to know the perception of the community about loss and gain/decreased and increased of plants species because the Dayak community is known for its habits to use the type of natural resources that exist around it. The existence of plants has essentially been of great value to indigenous peoples, in accordance with archaeological evidence often used to show that at the beginning of civilization and human dependence on plants were used to survive by taking from natural resources for food [24].

The types of plants that previously existed around NTYE are woody plants including Neolamarckia cadamba and Shorea sp. Then, there are also fruit trees such as forest durian/pekawai, red durian/kusik, and forest pare (Momordica sp). Some types of plants are considered loss because they cannot be found again by the community. But not all societies fully feel that these lost species bring the negative impacts to them, this is seen with most $(74.32 \%)$ people feeling that the existence of these species of plants is not considered as an alternative to their income (Table 3).

Table 3. Perceptions of Dayak Communities.

\begin{tabular}{|l|l|l|l|l|l|}
\hline No. & \multicolumn{1}{|c|}{ Statement } & \multicolumn{3}{c|}{ Perception (\%) } \\
\cline { 3 - 6 } & \multicolumn{1}{|c|}{$\begin{array}{c}\text { Do not } \\
\text { know }\end{array}$} & $\begin{array}{c}\text { Do not } \\
\text { Agree }\end{array}$ & Doubt & Agree \\
\hline 1 & Alternative Income Society & 0.00 & 74.32 & 18.92 & 6.76 \\
\hline 2 & $\begin{array}{l}\text { Oil Palm increase medicinal } \\
\text { plants }\end{array}$ & 17.57 & 75.68 & 0.00 & 6.76 \\
\hline 3 & Oil Palm increase food plants & 2.70 & 85.14 & 8.11 & 4.05 \\
\hline 4 & $\begin{array}{l}\text { Oil palm increase plants } \\
\text { diversity }\end{array}$ & 2.70 & 20.27 & 1.35 & 75.68 \\
\hline 5 & Easy to grow other plants & 0.00 & 10.81 & 0.00 & 89.19 \\
\hline
\end{tabular}

This happens because the existing community is not directly relying on economic activities involving plants that exist around them.

Considering medicinal uses, $(78 \%)$ of the people felt that the medicinal plants became increasingly difficult to find, as did the food plants with as many as (85.19\%) the community also found it increasingly difficult to find them. However, people who feel that the plants become more difficult to find do not feel lost because they are used to buy food in the market and to buy medicine at the nearest public health center. This is in accordance with the results from Purwanto [25] who showed that the traditional knowledge of society decreases due to socio-cultural changes that generally affect the social values, as the younger generation seek a more practical alternative. This lifestyle change in the modern direction is supported by the majority $(89 \%)$ of the community who feels that with oil palm plantations they can still grow other plants around their homes, so that some types of crops can be planted and nurtured by the community and sometimes used as a source of income. According to Danoesatro [26] and Giono [27], the yard is usually planted with a variety of 
seasonal plant species for everyday purposes. Household restrictions are often referred to as living barns, live stalls or live pharmacies (Lovadi et al 2013). Then, considering the diversity of plant species, most people (76\%) feel that in general, the existence of oil palm plantations around their places make the variety of plant species become increased. The types of plants referred by the community that considered as gained species consist of mushroom tankos (Volvarariella volvacea), bunga pukul delapan (Turnera ulmifolia), and also reeds (Imperata cylindrica).

\section{Conclusion}

The loss of medicinal and food plants was felt by most people although they did not feel directly the loss because before the oil palm plantations were established, the pattern of society habits in fulfilling food needs and medicine had already changed to a more modern lifestyle. The existence of some lost economic value of some plant species that was decreased individually or lost does not have a significant impact on people's lives, because these species are not intensively used Indeed. The change of plant diversity does not really impact the Dayak community life pattern, on the other hand there are benefits that can be taken such as from the gain plant species and also opportunities to increase economic prosperity with the presence of oil palm plantations.

\section{Suggestions}

The research about gain and loss biodiversity based on community perceptions is still rare, so in the future it is necessary to conduct research related to it in order to obtain a symmetrical result both from the ecological and social side.

\section{References}

1. C.P. Soni, Kearifan Lokal Masyarakat Adat Dayak Kanayaitn dalam Pengelolaan Hutan Adat (Marang) di Kampung Sidas Data Kecamatan Sengah Temila Kabupaten Landak Kalimantan Barat [skripsi]. DIY (ID) : Universitas Negeri Yogyakarta (2012)

2. E.B. Walujo, Keterintegrasian Ilmu Sosial dengan Ilmu-ilmu Lain di Indonesia. Bunga Rampai Metodologi Penelitian. Departemen Pendidikan dan Kebudayaan, Dirjen Pendidikan Tinggi, Direktorat Pembinaan Penelitian dan Pengabdian Masyarakat. 173 - 176 (1992)

3. Direktorat Jendral Perkebunan. (2016). Statistik Perkebunan Indonesia: komoditas kelapa sawit 2013-2015. Jakarta(ID): Direktorat Jenderal Perkebunan, Kementerian Pertanian.

4. Budidarsono et al, Oil palm plantation in Indonesia: the implications for migration. settlement/resettlement and local economics development, (2013)

5. L.A. Budiasih, Inventerisasi Jenis Tumbuhan yang Berkhasiat sebagai Obat di kawasan Hutan Baning Sintang Kalimantan Barat, Skripsi, Fakultas Pertanian Universitas Tanjung Pura Pontianak, (2005),

6. L.P. Koh, D.S. Wilcove, Cashing in palm oil for conservation. Nature 448: 993994, (2007) 
7. A. Zakaria , C. Theile, L. Khaimur, Policy, practice, pride and prejudice: review of legal, environmental and social practices of oil palm plantation companies of the Wilmar Group in Sambas District, West Kalimantan (Indonesia). Friends of the Earth Netherlands, Lembaga Gemawan, and KONTAK Rakyat Borneo, Amsterdam, the Netherlands, (2007).

8. B. Azhar, L.P. Chong, M. Zakaria, N. Hassan, M. Arif, Effects of monoculture and polyculture practices in oil palm smallholdings on tropical farmland birds. Basic and Applied Ecology 15:336-346, (2014).

9. K. Obidzinski, R. Andriani, H. Komarudin, A. Andrianto, Environmental and social impacts of oil palm plantations and their implications for biofuel production in Indonesia. Ecology and Society 17(1): 25, (2012)

10. E.B. Fitzherbert, M.J Struebig, A. Morel, How will oil palm expansion affect biodiversity?, Trends in Ecology \& Evolution 23: 538-545 (2008)

11. L.P. Koh, D.S. Wilcove, Is oil palm agriculture really destroying tropical biodiversity . Conservation Letters 1:60-64, (2008)

12. Y. Santosa, A.Sunkar, Erniwati, I. Purnamasari, Sejarah Perkembangan Status, Penggunaan Lahan, dan Keanekaragaman Hayati Kebun Sawit Indonesia [laporan riset]. Bogor (ID): Badan Pengelola Dana Perkebunan Sawit dan Lembaga Penelitian Pengabdian Kepada Masyarakat IPB, (2016)

13. [BPS] Badan Pusat Statistik. (2017). Kecamatan Nanga Tayap dalam Angka 2017. Ketapang (ID): BPS Kabupaten Ketapang.

14. Darmadi. Dayak asal-usul dan penyebarannya di Bumi Borneo (1). Vol.3, No. 2. (Sosial Horizon, Pontianak, 2016).

15. A Afandi, Perbandingan Persepsi Masyarakat Terhadap Hutan Rakyat Berbasis Karet Dan Kebun Kelapa Sawit [skripsi]. Bogor (ID) : Institut Pertanian Bogor, (2011).

16. A.Fauzi, Ekonomi Sumberdaya Alam dan Lingkungan : Teori dan Aplikasi. (Gramedia, Jakarta, 2004).

17. A. Sunkar, Y. Santosa, S.H Hasibuan. Identifikasi Peubah Sosial Ekonomi Penentu Keberhasilan Konservasi Keanekaragaman Hayati, Media Konservasi, (2017).

18. S.B. Brush, A non-market approach to proctecting biological research. In: Greaves, T. (editor). (Intelectual Property Right for Indigenous People. Oklahoma City: Society for Applied Anthropology, 1994)

19. D. Kaplan and R.A. Manners, Teori Budaya (terjemahan) Landung Simatupang. Pustaka Pelajar. Edisi III. 294 hal, (2003)

20. E.B. Walujo, Sumbangan Ilmu Etnobotani dalam Memfasilitasi Hubungan Manusia dengan Tumbuhan dan Lingkungannya, Jurnal Biologi Indonesia 7 (2): 375-391 (2011).

21. A. Sunkar, E. Amzu, S. Nurjannah. Peran Kawasan Bernilai Konservasi Tinggi Bagi Pelestarian Keanekaragaman Hayati di Perkebunan Kelapa Sawit Provinsi Riau, Risalah Kebijakan Pertanian dan Lingkungan, (2016).

22. I. Lovadi, R. Linda, Meliki. Etnobotani Tumbuhan Obat oleh Suku Dayak Iban di Desa Tanjung Sari Kecamatan Ketungau Tengah Kabupaten Sintang, Protobiont Vol 2 (3): 129 - 135, (2013).

23. E.B. Waluyo, Perkembangan pemanfaatan tumbuhan obat di luar Pulau Jawa. Prosiding Pemanfaatan Tentang Tumbuhan Obat dari Hutan Tropika Indonesia, (Institut Pertanian Bogor, Bogor,1991) 
24. E.B. Walujo, Etnobotani: Memfasilitasi penghayatan, pemutakiran pengetahuan dan kearifan lokal dengan mengguna-kan prinsipprinsip dasar ilmu pengetahuan. Prosiding Seminar Enobotani IV. (Cibinong Science Center-LIPI, 18 Mei 2009, 2009).

25. Y. Purwanto, T.chikmawati, D.Setiadi, J.Batoro, Pengetahuan Tentang Tumbuhan Masyarakat Tengger di Bromo Tengger Semeru Jawa Timur, WACANA Jurnal Sosial, (2011).

26. Danoesatro, Tumbuhan Obat Keluarga, (Penebar Swadaya, Jakarta, 1980)

27. W. Giono, Budidaya Tumbuhan Obat di Perkarangan, (Agromedia Pustaka, Jakarta, 2004) 